\title{
Effect of Organic Manures on Growth, Rhizome Yield and Quality Attributes of Turmeric (Curcuma longa L.)
}

\author{
M. Z. U. Kamal ${ }^{1}$ and M. N. Yousuf ${ }^{2}$ \\ ${ }^{1}$ Dept. of Soil Science, Bangabandhu Sheikh Mujibur Rahman Agril. University, Gazipur, Bangladesh \\ ${ }^{2}$ Spices Research Centre, Bangladesh Agricultural Research Institute, Gazipur-1701, Bangladesh \\ *Corresponding author and Email: ziassc@yahoo.com
}

Received: 18 July 2011

Accepted: 26 May 2012

\begin{abstract}
The investigation was carried out to evaluate the effect of different organic manures on turmeric with reference to vegetative growth, biomass production, rhizome yield and its attributes of turmeric (Curcuma longa L.). Turmeric showed better response to the application of organic manures. Plant with neem cake application had the taller plant $(79.30 \mathrm{~cm})$, maximum number of tillers per plant (5.40), leaf number (5.40), leaf area (44.09) leaf area index (0.429), fresh weight of halum ( 190.05g), fresh weight of root $(49.13 \mathrm{~g})$, fresh weight of rhizome per plant $(256.21 \mathrm{~g})$ and dry weight of halum (15.21g), dry weight of root (7.32 g), dry weight of rhizome per plant $(40.35 \mathrm{~g})$, total dry matter yield $\left(6.85 \mathrm{t} \mathrm{ha}^{-1}\right)$ than those received other types of manures. Moreover, yield attributes such as number of mother rhizomes per plant ${ }^{-1}(1.75)$, more number of primary rhizomes per plant ${ }^{-1}(5.19)$, secondary rhizomes per plant $^{-1}$ (18.03) and tertiary rhizomes per plant (7.69) were also highly accelerated by neem cake application. Similarly, the same treatment expressed the best in terms of size of mother rhizome $(7.69 \mathrm{~cm})$, primary rhizome $(21.86 \mathrm{~cm})$ and secondary rhizomes $(7.05 \mathrm{~cm})$. All these parameters in cumulative contributed to produce the highest estimated fresh rhizomes yield \& cured rhizomes yield (29.48 $\mathrm{t} \mathrm{ha}^{-1}, 5.59 \mathrm{t} \mathrm{ha}^{-1}$ respectively). The highest curing percentage (20.28) was observed in $\mathrm{T}_{3}$ treatment having mustard cake@ $2.0 \mathrm{t} / \mathrm{ha}$. Thus, organic manure like neem cake was best fitted natural fertilizer for turmeric cultivation.
\end{abstract}

\section{Keywords: Organic manures, Curcuma longa L., rhizome yield}

\section{Introduction}

Turmeric (Curcuma longa L.) is an herbaceous perennial plant belonging to the family, Zingiberaceae and order Scitaminae. It is an ancient, most valuable, sacred spice of Bangladesh that contains appreciable quantities of proteins $(6.3 \%)$, lipids $(5.1 \%)$, carbohydrates $(69.4 \%)$ and fibre $(2.6 \%)$. Turmeric is rich in minerals like phosphorus, calcium, iron and vitamin A. Turmeric is a horticultural root-crop that is important not only as a spice and cosmetic, but also as a medicinal plant worldwide (Hermann and Martin, 1991; Osawa et al., 1995; Sugiyama et al., 1996; Nakamura et al., 1998; Ishimine et al., 2003; Hossain et al., 2005ab).

Turmeric originated in South-East Asia. It is grown in Bangladesh in about 16.06 thousand hectare with an annual production of 41.50 thousand tons (BBS, 2009). Bangladesh 
produces nearly 20 per cent of its total demand and the rest is imported. So, cultivation of turmeric should be emphasized.

Turmeric being a long duration (8-9 months) exhaustive crop responds well to nutrition. Hence, optimum dose of nutrients is essential to get good yield. Chemical fertilizer, herbicide and pesticide used in agriculture for increasing yield and controlling weeds and pests can contaminate the water, air and food, decrease soil fertility, inhibit growth of soil microorganisms and hazard human health (Parr et al., 1991). This negative effect of agricultural practices could be reversed by the correct utilization of manures and/ or crop residues within cropping system either alone or in combination with organic fertilizer (Mandal et.al, 2007). Beside these, utilization of organic manure in agriculture is recommended for retaining productivity of problem soils, reducing the usages of chemical fertilizer, improving economy in agriculture and minimizing environmental problems (Xiao et al., 2006). Organic farming assumes significant globally towards sustainable production and quality up gradation of turmeric (Sadaanadan, 1998).

The adverse effects of continuous use of high dose of chemical fertilizers on soil health and environment were realized; hence, the farmers are also showing considerable inclination towards traditional farming with least usage of fertilizers. The role of organic manures in improving soil structure and fertility is well understood. Organic manures have positive influence on soil texture and structure, better water holding capacity and drainage which in turn help for better growth and development of rhizomatous crop like turmeric (Kale et al., 1991).

Considering the economic importance of turmeric and environmental problems caused by chemicals application, it is important to cultivate turmeric using organic fertilizer. Different organic manures influence differently in terms of yield and quality of turmeric. Hence, it is necessary to know the best source of organic manure which could help in increasing the yield and quality. In view of this background, this study was aimed to evaluate the effect of different organic manures on turmeric yield and quality.

\section{Materials and Methods}

Field experiment was conducted during 20102011 using high yielding variety of turmeric BARI Halud-3, using different organic manure at Spices Research Centre, BARI, Gazipur. A description of some chemical properties of experimental soil collected from a depth of 0-15 $\mathrm{cm}$ prior to application of fertilizers is presented in Table 1. Soil analysis was done following ASI method (Hunter, 1984). The experiment was laid out in a randomized complete block design (RCBD) with three replications having five treatments: cowdung @ 15 t/ha, poultry manure @ 7.0 t/ha, mustard cake @ 2.0 t/ha. neem cake @ $2.0 \mathrm{t} / \mathrm{ha}$ and control (Without organic and chemical fertilizer). All of the manures were applied one week before sowing. Manure $\mathrm{pH}$ in $\mathrm{H}_{2} \mathrm{O}$ was determined with a TOA $\mathrm{pH}$ meter HM20S (Toa Electronic Ltd. Japan). Nitrogen concentration was determined following microKjeldahl method (Black, 1965). For determination $\mathrm{P} \& \mathrm{~K}$, plant samples were digested with nitric-perchloric acid solution and absorption of color was measured with spectrophotometer at $660 \mathrm{~nm}$ wavelength and flame photometer, respectively. Chemical compositions of the manures are presented in the Table 2. The crop was fertilized with $100 \mathrm{~kg} \mathrm{~N}$ ha-1, $100 \mathrm{~kg} \mathrm{P} \mathrm{ha}^{-1}, 87.5 \mathrm{~kg} \mathrm{~K} \mathrm{ha}^{-1} 13 \mathrm{~kg} \mathrm{~S}^{-1}$ and $2.5 \mathrm{~kg} \mathrm{Zn} \mathrm{ha}^{-1}$ as triple super phosphate (TSP), muriate of potash (MoP), zinc sulphate and gypsum, respectively. Half of nitrogen and all phosphorus, potassium, sulphur, zinc was applied at the time of final land preparation and the remaining nitrogen was applied at 80 and 110 DAP followed by irrigation. Rhizomes of BARI Halud-3 were planted in 20 April, 2010. All other agricultural practices were done according the Spices Research Centre recommendation for turmeric production (Anon., 2005). The crop was harvested at 12 February, 2011 after complete maturity, as indicated by the leaf 
drying and falling down of plants. To evaluate vegetative growth parameters and yield influenced by the manure, plant height, tiller number, leaf number, leaf area, leaf area index, leaf biomass, shoot biomass, total dry matter and yield (rhizomes number, weight, size, and rhizome dry matter) were recorded on five randomly selected plants in each of the treatment and mean was computed. Harvest index and curcumin content was done following the procedure suggested by Donald (1962) and Manjunath et al., (1991), respectively. Curing percentage was computed by deducting dry weight of rhizomes after curing from fresh weight of rhizomes and divided by fresh weight then multiplied by percentage. The data obtained were statistically analyzed by MSTATC computer software program (Bricker, 1991).

\section{Results and Discussion}

\subsection{Vegetative growth and biomass production}

Vegetative growth and biomass production of turmeric significantly influenced with all types of organic manure as presented in Table 3 . The plant grown in organic manure had the maximum plant height, number of tillers/plant, leaf area, leaf area index, fresh weight of (halum, root, rhizome, per plant) dry weight of (halum, root, rhizome, per plant ) and total dry matter compared to that of control. The plants with the manure remained green longer and had higher plant height, number of tiller, larger leaf area and greater leaf biomass and total dry matter (Table 3 ), which ultimately provided longer and higher photosynthesis process and resulted in a higher rhizome yield of turmeric. Similar results were obtained in previous studies (Ishimine et al., 2003; Hossain et al., 2005a). Among the treatments, the taller plant $(79.30 \mathrm{~cm})$ and maximum number of tillers per plant (5.40), leaf number (5.40), leaf area (44.09) leaf area index (0.429), fresh weight of halum (190.05g), fresh weight of root (49.13 g), fresh weight of rhizome per plant $(256.21 \mathrm{~g})$ and dry weight of halum (15.21g), dry weight of root (7.32 g), dry weight of rhizome per plant (40.35 g), total dry matter yield $\left(6.85 \mathrm{t} \mathrm{ha}^{-1}\right)$ were obtained from the treatment $\mathrm{T}_{4}$, with neem cake @ 2.0 t/ha. Although the vegetative growth and biomass production of $\mathrm{T}_{4}$ treatment were clearly identical to that of other organic manure treatments and it was statistically similar with another treatment $\mathrm{T}_{2}$ having poultry manure@ $7.0 \mathrm{t} / \mathrm{ha}$ except plant height and number of leaves/plant. However, leaf number and plant height increased slightly with the cow manure application than those with poultry manure (Table 3). The better performance of plants with neem cake was probably because it acted as natural fertilizer with pesticidal properties which protects plant roots from nematodes, soil grubs \& white ants and performs as a nitrification inhibitor and prolongs the availability of nitrogen to short duration as well as long duration crops. Beside these, it improves the soil condition considerably and protects the soil during the droughts. The manure provided nutrients (Table 2) to the plants and may improved edaphic factors, which resulted in higher vegetative growth parameters (Table 3). These results are in good agreement with the findings of several researchers which revealed that organic manuring increased the vegetative growth and biomass production effectively (Roy et al., 2010; Dinesh et al., 2010; Mohapatra \& Das, 2009; Manikerri, 2006)

\subsection{Yield \& quality of turmeric}

Significant differences were noticed for yield, yield attributes and quality of turmeric due to the application of various organic manures. Among the organic manures, neem cake followed by poultry manure was superior to cowdung with regard to yield and quality parameters (Table 4). The application of neem cake manure produced superior yield attributes like more number of mother rhizomes per plant ${ }^{-1}(1.75)$, more number of primary rhizomes per plant ${ }^{-1}(5.19)$, secondary rhizomes per plant ${ }^{-1}(18.03)$ and tertiary rhizomes per plant (7.69). Similarly the same treatment expressed the best in terms of size of mother rhizome $(7.69 \mathrm{~cm})$, primary rhizome $(21.86 \mathrm{~cm})$ and secondary rhizomes $(7.05 \mathrm{~cm})$. All these parameters in cumulative produced the 
Table 1. Analytical data of the experimental soil

\begin{tabular}{|c|c|c|c|c|c|c|c|c|c|c|c|c|c|}
\hline \multirow[b]{2}{*}{ Texture } & \multirow[t]{2}{*}{$\mathrm{pH}$} & $\mathrm{OM}$ & $\mathrm{Ca}$ & $\mathrm{Mg}$ & $\mathrm{K}$ & Total N & $\mathrm{P}$ & $\mathrm{S}$ & $\mathrm{B}$ & $\mathrm{Zn}$ & $\mathrm{Cu}$ & $\mathrm{Mn}$ & Mo \\
\hline & & $\%$ & \multicolumn{3}{|c|}{ (meq/100g soil) } & $\%$ & \multicolumn{7}{|c|}{ ( $\mu \mathrm{g} / \mathrm{g}$ soil) } \\
\hline Sandy loam & 6.2 & 1.1 & 2.9 & 0.9 & 0.33 & 0.069 & 47 & 29 & 0.17 & 1.9 & 0.08 & 2.2 & 0.05 \\
\hline Critical level & - & - & 2.0 & 0.8 & 0.20 & 0.12 & 14 & 14 & 0.2 & 2.00 & 0.2 & 1.0 & 0.1 \\
\hline
\end{tabular}

Table 2. Nutrient status of organic manure used in the experiment

\begin{tabular}{lccccccccccccc}
\hline \multicolumn{1}{c}{ Organic manure } & $\mathrm{pH}$ & $\mathrm{OM}$ & $\begin{array}{c}\mathrm{N} \\
\%\end{array}$ & $\begin{array}{c}\mathrm{K} \\
\%\end{array}$ & $\begin{array}{c}\mathrm{P} \\
\%\end{array}$ & $\begin{array}{c}\mathrm{Ca} \\
\mathrm{ppm}\end{array}$ & $\begin{array}{c}\mathrm{Mg} \\
\mathrm{ppm}\end{array}$ & $\begin{array}{c}\mathrm{S} \\
\mathrm{ppm}\end{array}$ & $\begin{array}{c}\mathrm{Fe} \\
\mathrm{ppm}\end{array}$ & $\begin{array}{c}\mathrm{Zn} \\
\mathrm{ppm}\end{array}$ & $\begin{array}{c}\mathrm{Cu} \\
\mathrm{ppm}\end{array}$ & $\begin{array}{c}\mathrm{Mn} \\
\mathrm{ppm}\end{array}$ & $\begin{array}{c}\mathrm{B} \\
\mathrm{Ppm}\end{array}$ \\
\hline Cow dung & 7.4 & 11.5 & 0.56 & 0.50 & 0.6 & 2800 & 1100 & 500 & 400 & 15 & 5 & 10 & 15 \\
Poultry manure & 7.9 & 17.4 & 1.56 & 0.35 & 1.5 & 37000 & 2900 & 3100 & 465 & 90 & 15 & 90 & 60 \\
Mustard cake & 7.2 & 16.0 & 5.1 & 1.8 & 1.2 & - & - & - & - & - & - & - & - \\
Neem cake & 7.0 & 11.5 & 5.03 & 1.4 & 0.44 & 48000 & - & - & 2705 & 19 & 19 & - & - \\
\hline
\end{tabular}


Table 3. Vegetative growth and biomass production of turmeric as influenced by different organic manure

\begin{tabular}{|c|c|c|c|c|c|c|c|c|c|c|c|c|}
\hline Treatments & $\begin{array}{l}\text { Plant } \\
\text { height } \\
(\mathrm{cm})\end{array}$ & $\begin{array}{l}\text { No. of } \\
\text { leaves }\end{array}$ & $\begin{array}{l}\text { No. of } \\
\text { Tillers } \\
\text { / plant }\end{array}$ & $\begin{array}{l}\text { Leaf } \\
\text { area } \\
\left(\mathrm{dm}^{2}\right)\end{array}$ & $\begin{array}{l}\text { Leaf } \\
\text { area } \\
\quad \text { Index }\end{array}$ & $\begin{array}{l}\text { Fresh } \\
\text { weight } \\
\text { of halum } \\
\text { (g/plant) }\end{array}$ & $\begin{array}{l}\text { Fresh } \\
\text { weight of } \\
\text { roots } \\
\text { (g/plant) }\end{array}$ & $\begin{array}{l}\text { Fresh } \\
\text { weight of } \\
\text { rhizome } \\
\text { (g/plant) }\end{array}$ & $\begin{array}{l}\text { Dry } \\
\text { weight of } \\
\text { halum } \\
\text { (g/plant) }\end{array}$ & $\begin{array}{l}\text { Dry } \\
\text { weight } \\
\text { of roots } \\
\text { (g/plant) }\end{array}$ & $\begin{array}{l}\text { Dry } \\
\text { weight of } \\
\text { rhizome } \\
\text { (g/plant) }\end{array}$ & $\begin{array}{l}\text { Total dry } \\
\text { Matter } \\
\text { (t/ha) }\end{array}$ \\
\hline T1 (Cowdung @ 15 t/ha) & 73.73 & 8.13 & 4.83 & 36.71 & 0.363 & 141.50 & 43.47 & 217.80 & 11.43 & 5.75 & 31.16 & 5.33 \\
\hline T2 (Poultry manure @ 7.0 t/ha) & 72.80 & 7.14 & 5.13 & 42.12 & 0.416 & 178.28 & 48.04 & 246.97 & 14.70 & 6.97 & 38.02 & 6.45 \\
\hline T3 (Mustard cake @ 2.0 t/ha) & 74.33 & 6.37 & 5.13 & 35.62 & 0.352 & 161.00 & 47.12 & 242.52 & 13.50 & 6.52 & 33.90 & 5.85 \\
\hline T4 (Neem cake @ 2.0 t/ha) & 79.30 & 8.67 & 5.40 & 44.09 & 0.429 & 190.05 & 49.13 & 256.21 & 15.21 & 7.32 & 40.35 & 6.85 \\
\hline T5 (Control) & 59.37 & 5.13 & 3.47 & 22.17 & 0.219 & 98.94 & 18.50 & 87.26 & 9.81 & 3.16 & 13.91 & 2.54 \\
\hline $\mathrm{CV}(\%)$ & 4.38 & 4.77 & 0.31 & 2.66 & 0.025 & 9.29 & 2.41 & 26.60 & 1.59 & 0.64 & 3.80 & 0.40 \\
\hline $\operatorname{LSD}(0.05)$ & 7.474 & 0.644 & 0.767 & 1.020 & 0.059 & 1.360 & 1.347 & 1.701 & 0.592 & 0.362 & 1.017 & 0.238 \\
\hline
\end{tabular}

Table 4. Yield, Yield attributes \& quality of turmeric as influenced by different organic manures

\begin{tabular}{|c|c|c|c|c|c|c|c|c|c|c|c|c|}
\hline Treatments & $\begin{array}{l}\text { No. of } \\
\text { Mother } \\
\text { Rhizome } \\
\text { s/plant }\end{array}$ & $\begin{array}{l}\text { No. of } \\
\text { Primary } \\
\text { rhizomes } \\
\text { /plant }\end{array}$ & $\begin{array}{l}\text { No. of } \\
\text { Secondary } \\
\text { rhizomes/ } \\
\text { plant }\end{array}$ & $\begin{array}{l}\text { No. of } \\
\text { tertiary } \\
\text { rhizomes } \\
\text { /plant }\end{array}$ & $\begin{array}{l}\text { Size of } \\
\text { Mother } \\
\text { Rhizome } \\
\mathrm{s}\left(\mathrm{cm}^{2}\right)\end{array}$ & $\begin{array}{l}\text { Size of } \\
\text { Primary } \\
\text { rhizomes } \\
\left(\mathrm{cm}^{2}\right)\end{array}$ & $\begin{array}{l}\text { Size of } \\
\text { Secondary } \\
\text { rhizomes } \\
\left(\mathrm{cm}^{2}\right)\end{array}$ & $\begin{array}{l}\text { Fresh } \\
\text { rhizome } \\
\text { yield } \\
\text { (t/ha) }\end{array}$ & $\begin{array}{l}\text { Curing } \\
(\%)\end{array}$ & $\begin{array}{l}\text { Cured } \\
\text { rhizome } \\
\text { yield } \\
\text { (t/ha) }\end{array}$ & $\begin{array}{l}\text { Harvest } \\
\text { Index }\end{array}$ & $\begin{array}{l}\text { Curcum } \\
\text { in } \\
\text { content } \\
(\%)\end{array}$ \\
\hline $\mathrm{T}_{1}$ (Cowdung@15 t/ha) & 1.46 & 3.87 & 16.15 & 4.65 & 6.28 & 15.73 & 4.62 & 21.17 & 19.21 & 4.36 & 0.63 & 3.31 \\
\hline $\mathrm{T}_{2}$ (Poultry manure @ $\left.7.0 \mathrm{t} / \mathrm{ha}\right)$ & 1.81 & 4.80 & 15.33 & 6.17 & 7.35 & 19.80 & 6.12 & 27.30 & 19.01 & 5.18 & 0.63 & 3.50 \\
\hline $\mathrm{T}_{3}$ (Mustard cake @ 2.0 t/ha) & 1.55 & 4.03 & 16.12 & 5.48 & 6.71 & 16.73 & 6.52 & 22.80 & 20.28 & 4.59 & 0.64 & 3.67 \\
\hline $\mathrm{T}_{4}($ Neem cake @ 2.0 t/ha $)$ & 1.75 & 5.19 & 18.03 & 6.08 & 7.69 & 21.86 & 7.05 & 29.48 & 19.03 & 5.59 & 0.63 & 3.73 \\
\hline $\mathrm{T}_{5}$ (Control) & 0.43 & 2.27 & 4.82 & 1.33 & 3.36 & 9.82 & 2.13 & 14.84 & 16.54 & 2.38 & 0.56 & 3.23 \\
\hline $\mathrm{CV}(\%)$ & 0.24 & 0.62 & 2.17 & 0.52 & 0.51 & 3.09 & 0.97 & 3.13 & 2.00 & 0.62 & 0.063 & NS \\
\hline $\operatorname{LSD}(0.05)$ & 0.198 & 0.179 & 0.589 & 0.381 & 0.206 & 0.639 & 0.429 & 0.473 & 0.309 & 0.206 & 0.060 & 0.061 \\
\hline
\end{tabular}


highest estimated fresh rhizomes yield \& cured rhizomes yield $\left(29.48 \mathrm{t} \mathrm{ha}^{-1}, 5.59 \mathrm{t} \mathrm{ha}^{-1}\right.$ respectively). The highest curing percentage (20.28) was excelled by the $T_{3}$ treatment having mustard cake@ 2.0 t/ha followed by $T_{1}$ treatment. Harvest index in all the organic manure management was almost similar except control. With regard to curcumin recovery percentage on turmeric, among the treatments, neem cake gave highest $(3.73 \%)$ followed by $\mathrm{T}_{3}$ treatment with mustard cake @2.0 t ha ${ }^{-1}(3.76 \%)$. Curcumin content was not statistically significant among the treatments. The lowest yield, yield attributes and quality was observed in control treatment. Although the yield and quality of turmeric was evidently the superior in the $\mathrm{T}_{4}$ treatment having neem cake @ $2.0 \mathrm{t} / \mathrm{ha}$ comparing with other organic manure impact, it was however, statistically similar to another treatment $T_{2}$ having poultry manure@ $7.0 \mathrm{t} / \mathrm{ha}$ except curcumin content percentage. Neem cake provided the best option for production of turmeric being an exhaustive crop because neem cake acts as usual fertilizer with pesticidal properties and enhances the organic carbon content of soil. Beside these, neem cake is an effective nitrogen inhibitor which helps of extends the availability of nitrogen for such high exhaustive crop; hence, the productivity of turmeric was probably increased. Previous studies reported that organic fertilizer improved soil productivity and fertility, which improved yield and quality of such long duration crop like turmeric (Hossain \& Ishimine, 2007; Velmurugan et al., 2007; Mohapatra \& Das 2009; Roy et al., 2010; Dinesh et al., 2010). Moreover, Manhas \& Gill (2010) found that application of FYM increased the growth, dry matter accumulation, yield and quality of turmeric.

\section{Conclusions}

It is concluded that application of cow dung, poultry manure, mustard cake and neem cake have significant influence on growth and yield parameters and quality of turmeric. However, plants with neem cake performed better in terms of yield and yield attributes than that of other manures. Therefore, a fertilization strategy that involves organic manure is crucial for nutrient exhaustive crops like turmeric for commercial cultivation.

\section{References}

Anonymous. 2005. Methods of Spices production technology (Bangla). Spices Research Centre, BARI. Shibgonj, Bogra, $12-13 \mathrm{pp}$.

BBS. 2009. Statistical Yearbook of Bangladesh, 2008. Bangladesh Bureau of Statistics, Ministry of Planning, Govt. of the People's Republic of Bangladesh, Dhaka. 586 p.

Black, C. A., Evans, D. D., White, J. L., Ensminger L. E. and Clark. F. E. 1965. Methods of soil analysis. Part I \& II. American Society of Agronomy, Inc. Madison, Wisconsin, USA $1367 \mathrm{p}$.

Bricker, B. 1991. MSTATC: A computer program for design management and analysis of agronomic research experiments. Crop and soil science Dept. MSU East Lancing, MI 48824, USA.

Dinesh, R. Srinivasan, V. Hamja, S. and Mahjusha, A. 2010. Short term incorporation of organic manures and fertilizers influences biochemicals and microbial characteristics of soils under an annual crop turmeric. Bioresource Technology, 101(12):4697-702.

Donald, C. M. 1962. In search of yield. Journal of Australian Institute of Agriculture, 28:171-178.

Hermann, P. T. A. and Martin, A. W. 1991. Pharmacology of Curcuma longa. Planta Medica, 57:1-7.

Hossain, M. A., Ishimine, Y., Akamine, H. and Motomura, K. 2005a. Effects of Seed Rhizome Size on Growth and Yield of Turmeric (Curcuma longa L.). Plant Production Science, 8 :86-94.

Hossain, M. A., Ishimine, Y, Motomura, K. and Akamine, H. 2005b. Effects of Planting 
Pattern and Spacing on Growth and Yield of Turmeric (Curcuma longa L.). Plant Production Science, 8:95-105.

Hossain, M. A. and Ishimine, Y. 2007. Effects of Farmyard Manure on Growth and Yield of Turmeric (Curcuma longa L.) Cultivated in Dark-Red Soil, Red Soil and Gray Soil in Okinawa, Japan. Plant Production Science, 10 (1): 146-150.

Hunter, A. H. 1984. Soil Analytical Services in Bangladesh. BARI/Aids Consultancy Report. Contract Aid/388-005, Dhaka. Bangladesh. 1-7 pp.

Ishimine, Y, Hossain, M. A, Ishimine, Y. and Murayama, S. 2003. Optimal planting depth for (Curcuma longa L.) cultivation in Darkred soil in Okinawa Island, Southern Japan. Plant Production Science, 6:83-89.

Kale, R. N., Bano, K. and Satyavati, G. P. 1991. Inlfuence of vermicompost application on growth and yield of cereals, vegetables and ornamental plants. Final report of KSCSI Project, N67004/Vermi (34B (3478), 27-29 pp.

Manhas, S. S. and Gill. B. S. 2010. Effect of planting materials, mulch levels and farmyard manure on growth, yield and quality of turmeric (Curcuma longa). The Indian Journal of Agricultural Scienc, 80(6): 227-233.

Manjunath, M. N., Sattigeri, V. D. and Nagaraj, K. V., 1991. Curcumin in turmeric. Spice India, 12: 7-9.

Mohapatra, S. C. and Das, T. K. 2009. Integrated effect of biofertilizers and organic manure on turmeric (Curcuma longa). Environment and Ecology, 27(3A): 1444-1445.

Mannikeri, I. M. 2006. Studies on Production Technology of Termeric (Curcuma longa L.) Doctor of Philosophy Thesis, Dept. of Horticulture, University of Agricultural Sciences, Dharwad, Karnataka, India. 1-125 pp.

Mandal, A., Patra, A. K., Singh D., Swarup, F and Masto R. E. 2007. Effect of long term application of manure and fertilizer on biological and biochemical properties in a silty loam soil under conventional and organic management. Soil Tillage Research, 90:162-170.

Nakamura, Y., Ohto, Y., Murakami, A., Osawa, T. and Ohigashi, H. 1998. Inhibitory effects of curcumin and tetrahydrocurcuminoids on tumor promoter-induced reactive oxygen species generation in leukocytes in vitro and in vivo. Japan Journal of Cancer Research, 89:361-370.

Osawa, T, Sugiyama, Y, Inayoshi, M. and Kawakishi, S. 1995.Antioxidative activity of tetrahydrocurcuminoids. Bioscience Biotechnology Biochemical, 59:1609-1612.

Parr, J. F., Hornick, S. B. and Whitman C. E. 1991. First International Conference on Kyusei Nature Farming. Proceedings of the Conference held October 17-21, 1989, at Khon Kaen, Thailand. 175 p.

Roy, S. S. and Hore, J. K. 2010. Vermiculture can be practised in all plantation crops. A report of Department of Spices and Plantation Crops, Faculty of Horticulture,Bidhan Chandra Krishi Viswavidyalaya, Mohanpur - 741 252, Nadia, West Bengal. 20-39 pp.

Sadanandan, A. K., Peter, K. V. and Hamza, S. 1998. Soil nutrient and water management for sustainable spices production. Proc. National seminar on water and nutrient management for sustainable production and quality of spices. ISS, IISR, Calicut, 5-6 Oct 1997. 12-20 pp.

Sugiyama, Y, Kawakishi, S. and Osawa, T. 1996. Involvement of the j3-diketone moiety in the antioxidative mechanism of tetrahydrocurcumin. Biochemical Pharmacology, 52: 519-525.

Velmurugan, M., Chezhiyan, N. and Jawaharlal, M. 2007. Studies on the effect of organic manures and biofertilizers on rhizome yield and its attributes of turmeric cv. BSR-2. The Asian Journal of Horticulture. 2 (2):23-29. 
